\title{
PENERAPAN AUDIOBOOK LIT2GO DALAM PEMBELAJARAN BAHASA INGGRIS DI LEMBAGA KURSUS
}

\author{
Maulana Yusuf Aditya \\ Jurusan Pendidikan Bahasa Inggris, STKIP PGRI Bangkalan \\ aditya@stkippgri-bkl.ac.id
}

\begin{abstract}
Abstrak
Kegiatan pengabdian kepada masyarakat ini merupakan kegiatan lanjutan dari program sebelumnya, dimana dilakukan pelatihan terkait penerapan teknologi dalam pembelajaran bahasa atau disingkat TELL (Technology in Language Learning). Seiring berkembangnya lembaga-lembaga kursus yang jumlahnya semakin banyak, terutama di wilayah Bangkalan. Banyak siswa-siswi mulai dari tingkat sekolah dasar sampai menengah atas mendaftar dan mengikuti program-program yang ditawarkan oleh lembaga kursus. Tren inilah yang menjadi dasar terpilihnya lembaga kursus sebagai tempat melakukan kegiatan pengabdian kepada masyarakat. Penerapan audiobook lit2go di lembaga kursus Bahasa Inggris ini dilakukan oleh para tutor di lembaga kursus E-Home untuk membantu proses pembelajaran dengan memanfaatkan teknologi pembelajaran, yang nantinya diharapkan bisa meningkatkan hasil belajar siswa. Hasil dari kegiatan pengabdian kepada masyarakat ini adalah meningkatnya kemampuan pengajar Bahasa Inggris di lembaga kursus dalam menggunakan teknologi saat pembelajaran, dalam hal ini penggunaan audiobook lit2go.
\end{abstract}

Kata kunci: Audiobook Lit2go, Tell, Pembelajaran, Teknologi

\begin{abstract}
This community service activity is a continuation of the previous program, where training is carried out related to the application of technology in language learning called TELL (Technology in Language Learning). As the number of course institutions grows, especially in the Bangkalan region. Many students ranging from elementary to high school level register and participate in programs offered by institute courses. This trend is the basis for the selection of course institutions as a place to do community service. The application of lit2go audiobook at English language course institutions is carried out by tutors at E-Home course institutions to assist the learning process by utilizing learning technology, which in turn is expected to improve student learning outcomes. The result of this community service activity is the improvement of the ability of English teachers in course institutions to use technology while learning, in this case the use of lit2 go audiobook.
\end{abstract}

Keywords: Lit2go Audiobook, Tell, Learning, Technology 


\section{A. Pendahuluan}

Bahasa adalah salah satu elemen penting yang mempengaruhi kegiatan komunikasi internasional. Siswa menggunakan berbagai bagian keterampilan bahasa Inggris seperti mendengarkan, berbicara, membaca, dan menulis untuk kemahiran dan komunikasi mereka (Grabe \& Stoller, 2002)

Membaca adalah keterampilan penting bagi siswa untuk mendapatkan pengetahuan dan informasi dari teks tertulis. Dalam membaca, siswa diharapkan mendapatkan pengetahuan tentang apa yang telah dijelaskan dalam teks, sedangkan dalam membaca Pemahaman siswa juga diharapkan untuk menggunakan keterampilan mereka untuk memproses informasi untuk menjadi pembaca yang lancar. Faktanya, pemahaman membaca tidak semudah yang dipikirkan orang. Tidak mudah memiliki kemampuan mendeskripsikan makna dari halaman yang dicetak dan kemudian menginterpretasikan informasi dengan tepat.

Teknologi selalu menjadi bagian penting dari lingkungan belajar dan mengajar. Ini adalah sebuah bagian penting dari profesi guru dimana mereka dapat menggunakannya untuk memfasilitasi peserta didik belajar. Ketika kita berbicara tentang teknologi dalam pengajaran dan pembelajaran, kata 'integrasi' digunakan. Dengan teknologi yang menjadi bagian dari kehidupan kita sehari-hari, sekarang saatnya untuk memikirkan kembali ide integrasi teknologi ke dalam kurikulum dan bertujuan untuk menanamkan teknologi ke dalam pengajaran untuk mendukung pembelajaran proses. Artinya, teknologi menjadi bagian integral dari pengalaman belajar dan merupakan masalah signifikan bagi guru yang dari awal menyiapkan pengalaman belajar hingga proses belajar mengajar (Eady \& Lockyer, 2013).

Zhao (2005) menambahkan bahwa komputer dan papan tulis interaktif semakin umum di sekolah-sekolah dan kecepatan di mana sekolah dapat terhubung satu sama lain terus meningkat. Untuk teknologi guru dan siswa sekarang seperti komputer laptop, perangkat tablet, dan ponsel cerdas adalah bagian yang harus ada dalam konteks belajar mengajar di sekolah. Semakin banyak guru dan administrator sekolah menerima peran sumber daya digital dan internet, mereka dapat semakin berperan dalam meningkatkan level motivasi dan keterlibatan dalam pembelajaran, mendukung peserta didik dengan 
gaya belajar yang berbeda dan membantu meningkatkan kualitas pengajaran dan pembelajaran.

Berdasarkan penjelasan diatas bahwa penerapan teknologi sudah sangat massive dilakukan di sekolah-sekolah, sedangkan hal tersebut tidak terjadi di beberapa lembaga kursus di Bangkalan. Karena itulah pelatihan-pelatihan mengenai penerapan teknologi dalam pembelajaran harus banyak dilakukan, khususnya kepada tutor atau pengajar di lembaga kursus.

Penggunaan teknologi yang tidak memadai dalam membantu proses belajar mengajar membuat siswa bosan dengan cepat dan akhirnya membuat subjek tidak sepenuhnya disampaikan. Maka dari itu sangat penting untuk memperbarui teknik/metode yang digunakan sehingga siswa dapat secara optimal menyerap materi yang diberikan oleh pengajar. Berdasarkan kondisi ini, dianggap penting untuk mengimplementasikan kegiatan pengabdian kepada masyarakat ini dalam bentuk pelatihan implementasi audiobook lit2go di lembaga kursus Bahasa Inggris e-Home.

\section{B. Metode Pelaksanaan}

Kegiatan pengabdian kepada masyarakat ini dilakukan di lembaga kursus Bahasa Inggris e-Home di Jl. KH. Abdul Mu'in 84 Bangkalan. Kegiatan ini dilakukan selama 5 hari, dari hari Senin sampai Rabu tanggal 14 - 16 Oktober 2019.

Berdasarkan pada permasalahan mitra yang telah dijelaskan di atas, pemateri menggunakan metode pelatihan penerapan audiobook lit2go dalam pembelajaran Bahasa Inggris di lembaga kursus Bahasa Inggris e-Home. Pelatihan ini diharapkan dapat membantu para tutor dalam implementasi pembelajaran menggunakan teknologi yakni menggunakan audiobook lit2go untuk meningkatkan hasil belajar siswa dan membuat siswa enjoy di dalam kelas.

Fasilitas yang diperlukan selama pelatihan antara lain LCD dan proyektor, juga laptop dan internet. Pemateri menggunakan power point untuk menyampaikan materi pelatihan sehingga tutor/pengajar dapat memahami dan menggunakan audiobook lit2go.

\section{Hasil dan Pembahasan}




\section{Hasil}

Kegiatan pelatihan penerapan audiobook lit2go dalam pembelajaran Bahasa Inggris di lembaga kursus Bahasa Inggris e-Home di Bangkalan melalui satu tahapan yakni tahapan pemberian pelatihan penerapan audiobook lit2go dengan alokasi waktu selama 3 (tiga) hari yang menghasilkan beberapa data atau informasi sebagai berikut:

1. Pelaksanaan kegiatan pelatihan penerapan audiobook lit2go dilakukan seperti Workshop. Peserta membawa perangkat masing - masing untuk menggunakan dan mengimplementasikan audiobook lit2go sehingga semua peserta dapat fokus belajar dan mengerti serta menggunakan audiobook lit2go.

2. Peserta merupakan para tutor di lembaga kursus Bahasa Inggris e-Home di kecamatan Bangkalan, kabupaten Bangkalan.

3. Berdasarkan hasil observasi, dapat disimpulkan bahwa pelaksanaan pelatihan berlangsung lancar, efektif dan berhasil.

4. Terdapat peningkatan kemampuan para pengajar dalam memanfaatkan website sebagai media dalam proses belajar mengajar.

\section{Pembahasan}

Berdasarkan hasil observasi lapangan kepada peserta pelatihan penerapan audiobook lit2go dalam pembelajaran Bahasa Inggris di lembaga kursus, menunjukkan bahwa pelatihan tersebut membuka wawasan para tutor/pengajar mengenai pemanfaatan website-website yang bisa diakses menggunakan internet, yang salah satunya adalah audiobook lit2go.

Di hari pertama pelatihan, para peserta mendapatkan sosialisasi mengenai pembelajaran yang memanfaatkan teknologi, dalam hal ini website. Pemateri menampilan website dan aplikasi yang sudah sering digunakan seperti google classroom dan edmodo. Pemateri juga menambahkan penjelasan mengenai perkembangan internet masa kini yang sudah mendekati era $5 \mathrm{G}$.

Di hari kedua pelatihan, Pemateri memulai pelatihan tentang apa dan bagaimana menggunakan website audiobook lit2go kepada peserta. Tidak hanya menggunakan media power poin, pemateri juga menggunakan video untuk mempermudah peserta 
dalam memahami materi pelatihan. Pada kegiatan ini, pemateri melibatkan 5 (lima) mahasiswa Jurusan Pendidikan Bahasa Inggris untuk membantu dan memperlancar proses pelatihan. Karena pelatihan ini sangat tidak mungkin dilakukan seorang diri.

Di hari terakhir pelatihan, pemateri meminta peserta melakukan micro teaching dengan menerapkan audiobook lit2go di dalam kelas, secara bergantian dengan peserta lain menjadi guru dan siswa dalam micro teaching tersebut. Sedangkan pemateri menjadi pengamat yang nantinya akan membetulkan dan memberi saran setelah micro teaching selesai dilakukan.

\section{Kesimpulan}

Berdasarkan hasil dari pelatihan penerapan audiobook lit2go dalam pembelajaran Bahasa Inggris di lembaga kursus, terdapat beberapa kesimpulan antara lain:

1. Kegiatan pengabdian kepada masyarakat yang dalam hal ini dilakukan seperti workshop, mendapat respon positif dari peserta. Karena kegiatan ini adalah hasil dari kegiatan pengabdian kepada masyarakat yang sebelumnya, dimana peserta menginginkan adanya kegiatan serupa dikemudian hari.

2. Kegiatan ini membuka pengetahuan dan wawasan kepada para peserta mengenai websitewebsite pembelajaran yang bisa digunakan secara gratis.

3. Penerapan audiobook lit2go dalam pembelajaran Bahasa Inggris mempermudah pengajar di dalam kelas, hal tersebut juga berdampak kepada respon dan hasil belajar siswa yang semakin meningkat. 


\section{DAFTAR PUSTAKA}

Eady, M. J., \& Lockyer, L. (2013). Tools for learning: technology and teaching strategies: Learning to teach in the primary school. Queensland University of Technology, Australia. pp. 71-89. https://scholars.uow.edu.au/display/publication76376

Grabe, W., \& Stoller, F. L. (2002). Teaching and researching reading. New York: Pearson Education. doi: 10.4324/9781315833743

Karwati, E. (2014). Pengaruh Pembelajaran Elektronik (E-Learning) Terhadap Mutu Belajar Mahasiswa. Jurnal Penelitian Komunikasi Vol. 17 No. 1 hal. 41-54.

Maryani, Y. (2013). Aplikasi E-Learning Sebagai Model Pembelajaran Berbasis Teknologi informasi di Jurusan Kesehatan Gigi Poltekkes Kemenkes Pontianak. Vo. 9 No. 1 hal. 27-39.

Zhao.Y. (2005) (Ed).Research in technology and second language learning. Connecticut: IAP Publishing. 